\title{
Human Embryo Neuronal Culture in Vitro: A Model to Study Cellular Physiology, Receptors, Power and Toxicity of Cytostatic Drugs for Human Use
}

\author{
Stabile Mariano ${ }^{1}$, Monaco Roberto ${ }^{2}$, Iuorio Tina1, Buoninfante Luca ${ }^{3}$, Marino Lucia ${ }^{1}$, \\ Altieri Vincenzo ${ }^{4}$, Della Ragione Carlo ${ }^{2}$, Masillo Francesco ${ }^{3}$ \\ ${ }^{1}$ ZigoteGenetic and Prenatal Diagnosis Centre, Salerno, Italy; ${ }^{2}$ Anatomy Pathology Department, Hospital “A. Cardarelli”, Naples, \\ Italy; ${ }^{3}$ Department of Gynecology and Obstetrics, Hospital "Maria SS Addolorata”, Eboli, Italy; ${ }^{4}$ Genetic Department, Hospital \\ “Elenad’ Aosta”, Naples, Italy. \\ Email: zigote@tiscalinet.it
}

Received May $14^{\text {th }}, 2012$; revised June $14^{\text {th }}, 2012$; accepted June $22^{\text {nd }}, 2012$

\begin{abstract}
Neural cells cultures from human embryo brain of $9^{\circ}-11^{\circ} \mathrm{W}$ gestational age have been used to study ER $\alpha$ (Estrogens Receptor $\alpha$ ) and to perform toxicity test for Mitomycin C and Methotrexate. Histochemical confirmation of cellular neuronal phenotype was based on histochemical evidence of NSE (Neuron Specific Enolase).The detection of ER $\alpha$ in neuronal cells was performed with a rabbit Monoclonal Antibody. ER $\alpha$ was absent both on neurons grown in vitro and on tissue brain specimens. This finding is apparently in contrast with the positive immunoreactivity of $\operatorname{ER} \alpha$ and $\operatorname{ER} \beta$ reported by other Authors on foetal and adult CNS (Central Nervous System). The absence of nuclear ER $\alpha$ on neurons in culture and in brain tissue specimens in our experiment is not in contrast with the relevant physiologic role of estrogens on nervous central system, but it could be correlated to the embryonic period of life and could represent a protection of male brain from an undue estrogens imprinting. The mitomycin C, alkylation agent, has shown in our experiment a major neurotoxic and cytostatic power in comparison with methotrexate. Our conclusion is that human embryo neuronal culture in vitro is a powerful instrument for physiology and human therapy for cancer and neurodegenerative diseases.
\end{abstract}

Keywords: Human Embryo Neuronal Culture; ER $\alpha$ on Embryonic Brain; Mitomycin C Toxicity Test in Vitro; Methotrexate Toxicity Test in Vitro

\section{Introduction}

Neural cells culture has been successfully accomplished from neural precursors from marine embryonic stem cell [1] and from human ones [2].

The aim of the above mentioned researches was to obtain neural progenitors fit to integrate in vivo into a host tissue in order to replace damaged or absent neurons [3-6].

Our in vitro model, that is the culture of well differentiated neurons and not stem cells, from human embryo brain, is important for the research on hormones, drugs, neuromediators receptors with the aim to understand their role in morphogenesis and a potential therapeutic use or neurotoxicity.

In addition, an original contribution of our paper is the study of estrogens receptor $\mathrm{ER} \alpha$ on neurons in culture and toxicity test for Mitomycin C and Methotrexate on neurons in vitro.

\section{Materials and Methods}

\subsection{Embryos Collection}

We have obtained the positive judgement by the ethic committee (Prot. n. 47519/I3D7 Asl Sa 2 the 25.08.2005) for use of embryonic material from voluntary abortion.

The gestational age of the pregnant women were between $9^{\circ}-11^{\circ} \mathrm{W}$; an expert pathologist was in operating room in order to collect the embryo just delivered, enucleate brain and spinal medulla and, after washing, place the material in medium culture. Fragmented embryos were not selected for experiments.

\subsection{Neurons in Vitro Culture}

Brain and spinal medulla were gently cutted in a Petri dish, put in a sterile solution of Collagenase Type I 176.0 units/mg (Gibco) at a concentration of $1 \mathrm{mg} / 100 \mathrm{ml}$. After 2 hours of incubation at $37^{\circ} \mathrm{C}$ in atmosphere of $\mathrm{CO}_{2}$ 
$5 \%$, the material was collected in conical tube and centrifuge at $1500 \mathrm{rpm}$ for $10 \mathrm{~m}$ '. Thereafter, the sediment was suspended in culture medium B-27 Electrophysiology Kit (Invitrogen) specially formulated to promote an increased density of synapses and neurotransmitter receptors; $1 \mathrm{ml} / 100$ of antibiotic antimycotic solution $(100 \times)$ (Sigma) was added to the culture medium. The cellular suspension was plated in glass Petri dishes having in the centre a glass slide Superfrost plus (Thermo Scientific Menzel-Glaser) $25 \times 75 \times 1 \mathrm{~mm}$, in order to have a neuronal growth directly on glass slide fit to histochemical analysis; Superfrost plus has an electrostaticcally surface which binds better the cells.

Contrast phase microscope observation at 2, 4, 6 and 8 days from setting up the primary culture evidenced the growth of typically shaped neuronal cells with prolongations and synapses between cellular processes (Figure 1).

Only three out of the six originally embryo culture were successfully performed for a period of about 30 days; the other 3 cultures failed because bacterial and yeast contamination (too high the initial microbial load).

The embryo sex was established by FISH on interphase neurons culture; the sex was female for all three. In addition the complete karyotype was successfully obtained through treatment for cytogenetic investigation of neuron cultures.

\subsection{Histochemical Confirmation of Neuronal Phenotype}

High concentration of Neuron Specific Enolase (NSE) are present in neurons and in neuroendocrine lineage. For this reason we have used the Mouse Monoclonal Antibody anti-NSE (Neuron Specific Enolase-Ventana Medical System, Inc.) that reacts with NSE localized in the neuronal cytoplasm cells (Figure 2).

\section{Detection of ER $\alpha$ in Neurons in Vitro and in Brain Specimens}

Detection of Estrogen Receptor (ER $\alpha)$ in neuronal cells was performed with a rabbit Monoclonal Antibody (IgG) (CONFIRM Estrogen Receptor-Ventana Medical System, Inc.), that is intended for laboratory use for the qualitative detection of ER antigen. It is directed against an epitope present on human ER protein.

The cells that have in their nucleus the Estrogen Receptor stain brown and result positive. Absence of nuclear histochemical stain of ER $\alpha$ is shown in Figure 3(a) and absence of immunoreactivity $\mathrm{ER} \alpha$ of embryonic brain specimens fixed in formalin in Figure 3(b).

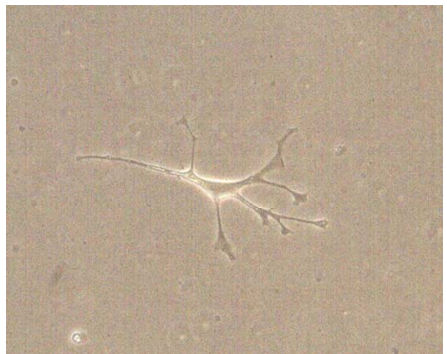

(a)

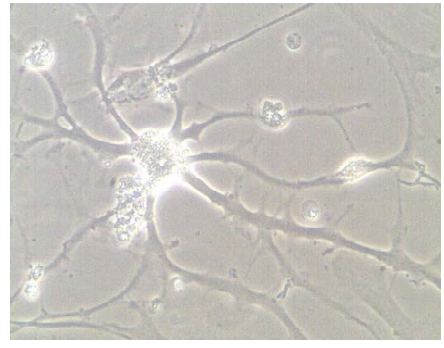

(b)

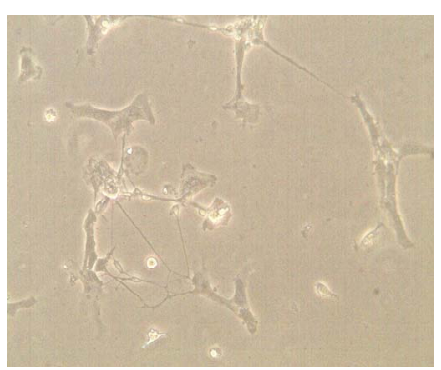

(c)

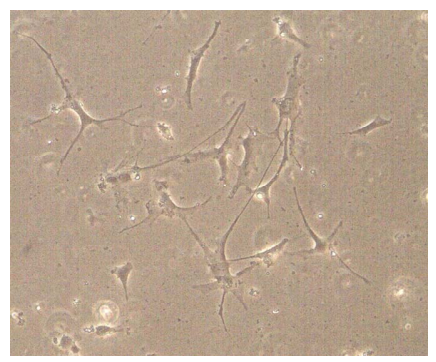

(d)

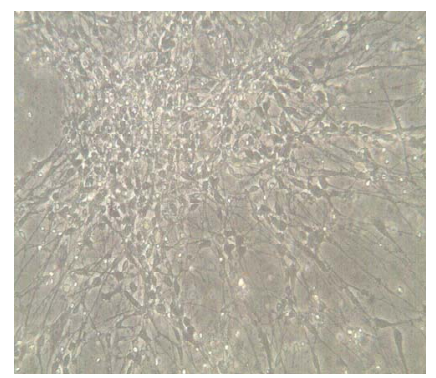

(e)

Figure 1. Neuronal culture: (a) After 2 days; a1 typical neuron; (b) Protoplasmic astrocyte; (c) After 4 days; (d) After 6 days; (e) After 8 days. Neuronal synapses are yet evident by the 4 days. 


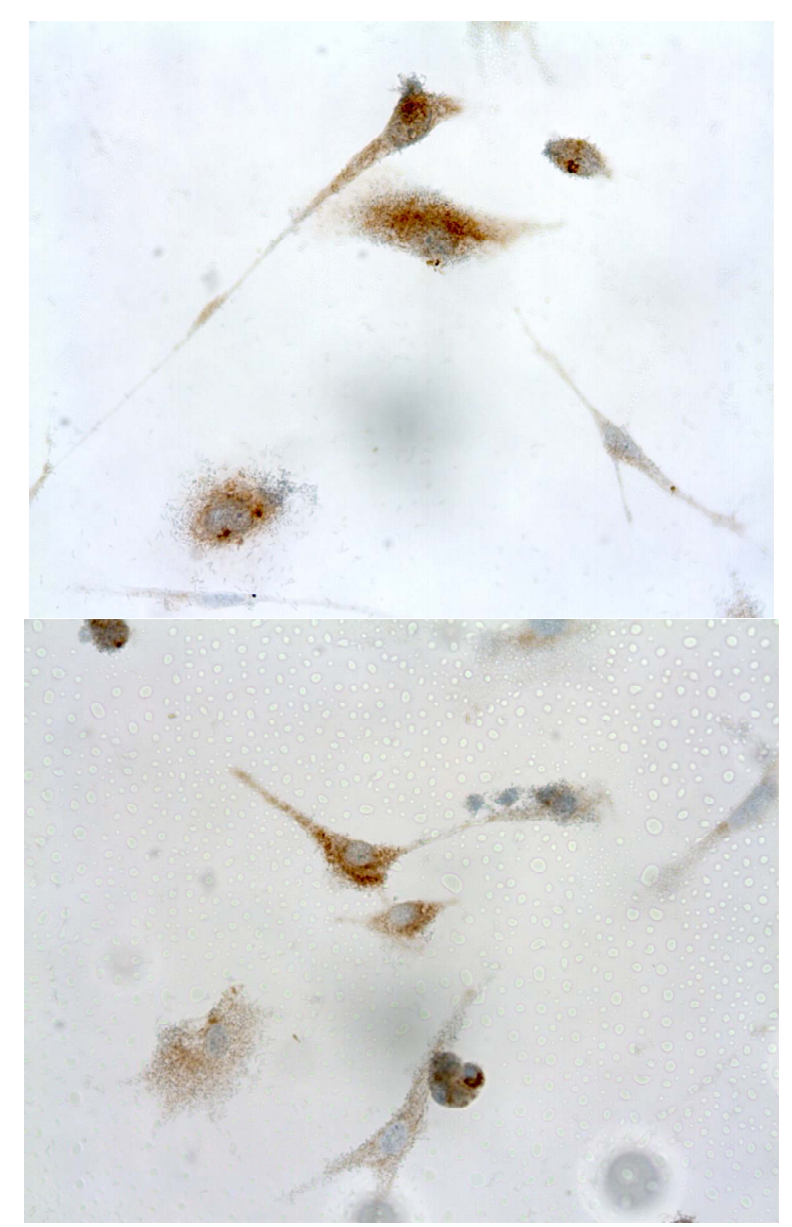

Figure 2. Immunohistochemical positivity for NSE (Neuronal Specific Enolase) of the neuron grown on glass slide: staining with anti-NSE antibody is uniformly intense on the cytosol of the cells confirming the neuronal phenotype.

\section{Toxicity Test in Vitro for Two Antineoplastic Drugs: Mitomycin C and Methotrexate}

The toxicity of the two drugs has been evaluated on two distinct subcultures in flasks from a primary culture of embryonic neurons.

Both has been added to the culture medium with a final concentration of $50 \mu \mathrm{g} / \mathrm{ml}$, comparable to blood concentrations used in human cancer therapy [7].

After 48 hours from the administration of Mitomycin C (Mitomycin C $10 \mathrm{mg}$, Kyowa Pharmaceuticals), the culture showed clear signs of cellular suffering with most of the cells in suspension (Figure 4).

Instead, the culture with Methotrexate (Metotrexate 5 mg, Lederle Pharmaceuticals) did not show, after 48 hours, any sign of cytopathy or detachment from the surface monolayer and proliferation was non apparently inhibited (Figure 5).

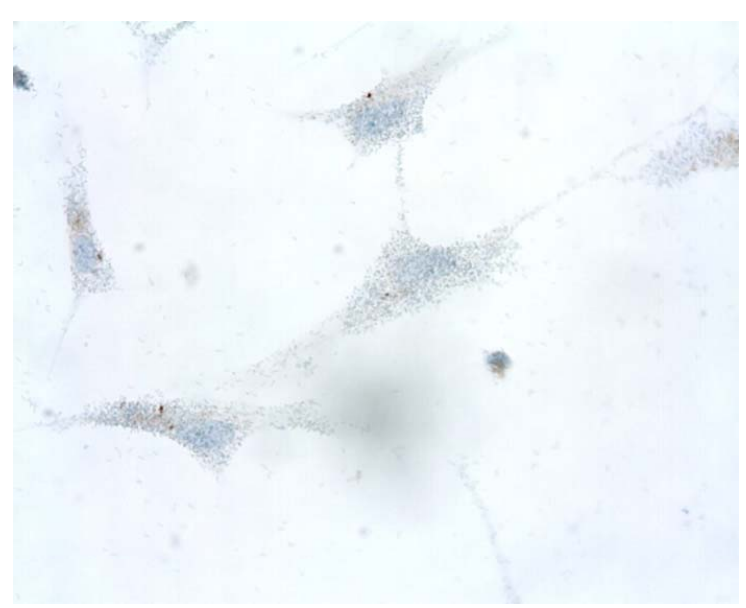

(a)

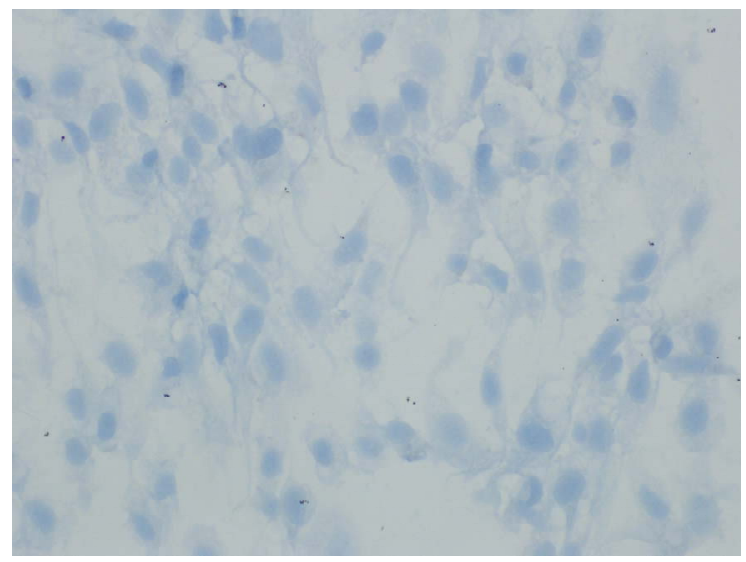

(b)

Figure 3. Histochemical stain of $\mathrm{ER} \alpha$ with a rabbit Monoclonal Antibody (IgG) (CONFIRM Estrogen ReceptorVentana Medical System, Inc.): (a) Absence of brown coloration indicating absence of $\mathrm{ER} \alpha$ protein, in neurons in vitro; (b) In brain tissue.

\section{Discussion}

Human embryonic neurons from spinal cord in culture have been obtained by Kato A. C. et al. 1985 [8]: biochemical studies demonstrate a prevalence of cholinergic and GABAergic neurons.

Sah D. W. 1995 [9] has studied voltage and ligandgated currents in human foetal central neurons in culture.

Human embryonic neuronal cultures have been established in our laboratory without particular difficulty. The more critical step of the procedure is the collection of material: an expert operator must be present in the surgical room and has to select embryonic material immediately after the expulsion. A further careful micro-dissecttion of the material has been performed in laboratory; it is better to initiate the culture with a reduced quantity ( 5 $10 \mathrm{mg}$ ) of embryonic nervous tissue material instead of a contamination with other cellular type. More than $90 \%$ of 


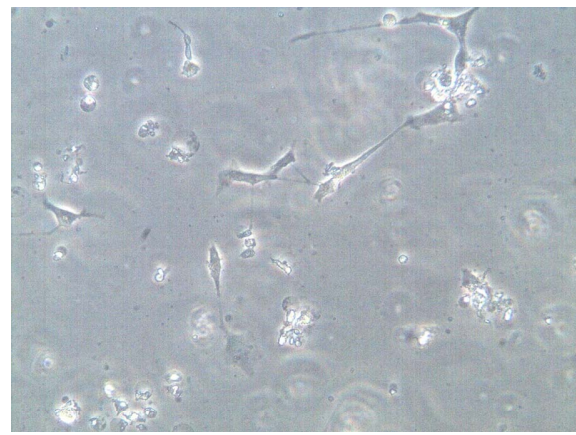

Figure 4. Mitomycin $C$ added neuronal culture: reduction of cellular prolongations and many cells are in suspension was yet evident at 2 days from subcultures.

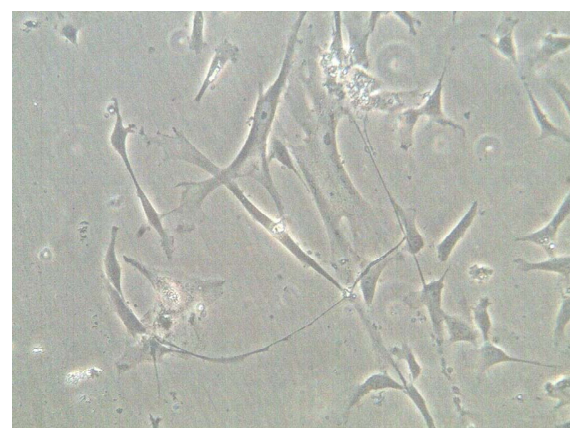

Figure 5. Metotrexate added neuronal culture: no cytotoxic effect of metotrexate was apparent at 2, 4, 6 days from subculture.

cells in vitro in our experiment are neurons, astrocytes, oligodendrocytes and Neural Stem Cell on the basis of morphological aspect and histochemical study.

A protective rule of estrogens in neurodegenerative diseases has been postulated [10,11].

The two types of Estrogens Receptors (ERs), ER $\alpha$ and $\mathrm{ER} \beta$, belong to the nuclear receptor superfamily, a family of ligand-regulated transcription factor. Both receptors are coexpressed in a number of tissue and form homodimers $(\alpha / \alpha, \beta / \beta)$ and heterodimers $(\alpha / \beta)$ [12]. When coexpressed, $\operatorname{ER} \beta$ inhibits the $\operatorname{ER} \alpha$ mediated gene expression. In mice $\mathrm{ER} \alpha$ is expressed primarily in the uterus, liver, kidney, and heart, whereas $\operatorname{ER} \beta$ is expressed primarily in the ovary, prostate, lung, gastrointestinal tract, bladder, hematopoietic and central nervous systems [13-15]. Cells containing immunoreactive estrogen receptor-alpha have been found in the human basal forebrain [16,17]. Differential Expression of Estrogen Receptor $\alpha$ and $\beta$ immunoreactivity has been found in the Human Supraoptic Nucleus (dl-SON) in Relation to Sex and Aging [18]. Significant correlations between the percentage of $\mathrm{ER} \beta$ - and $\mathrm{ER} \alpha$-positive and -negative AVP (Plasma Arginine Vasopressin) neurons and age were found in women, but not in men: a strong decrease of ER $\beta$ and an increase of $\mathrm{ER} \alpha$ immunoreactivity in AVP neu- rons of the dl-SON of postmenopausal women. Both receptor changes could participate in the activation of the AVP neurons in postmenopausal women.

Estrogen receptors localization in the human spinal trigeminal nucleus has been evidenced by Fenzi e Rizzuto [19].

Although ER subtypes may be expressed in the same tissue, they may not be expressed in the same cell type. Nonetheless, $\operatorname{ER} \alpha$ and $\operatorname{ER} \beta$ proteins have been simultaneously detected in many cell types including neurons. The absence of nuclear ER $\alpha$ on neurons in culture and in brain tissue specimens in our experiment is not in contrast with the relevant physiologic role of estrogens on nervous central system, but it could be correlated to the embryonic period of life and could represent a protection of male brain from an undue estrogens imprinting. A role of progesterone in inducing human embryonic stem cell proliferation and differentiation into neuroectodermal rosettes has been established [20].Considering that the two hormones, estrogens and progesterone, often have an antagonistic effect, the absence of $\mathrm{ER} \alpha$ receptor in embryonic brain could have its significance in non-antagonize the morphogenetic effect of progesterone.

Mitomycin $\mathrm{C}$ and metotrexate are antineoplastic drugs present in many polichemiotherapic schedules, including brain cancer.

The mitomycin $\mathrm{C}$, alkylating agent, has shown in our experiment a major neurotoxic and cytostatic power in comparison with methotrexate.

Metotrexate, competitive antagonist of the folic acid on catalytic site of the dihydrofolate reductase (DHFR), has an action which can be weakened by three factors: the reduction of polyglutamate inside the cell, increase of DHFR by genetic amplification, reduction of intracellular transport [7]. Therefore the apparent absence of neurotoxic effect in our model need a more complex experimental design to be explained. Nevertheless, the therapeutic index of Metotrexate is better than Mitomycin C on the basis of our experimental finding.

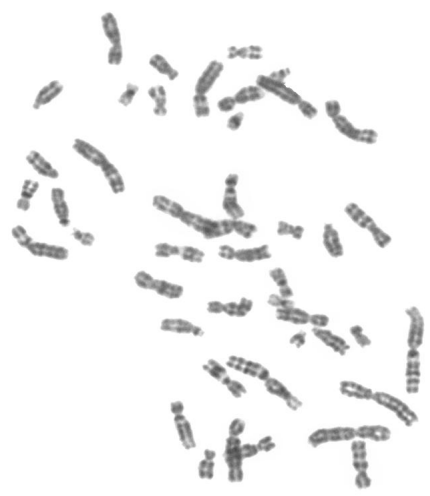

Figure 6. Metaphase with GTL banding from human neurons in culture. 
The cytogenetic investigation has easily been performed on our human embryonic neurons (Figure 6); the analysis of chromosomal fragility and SCE (Sister Chromatide Exchange) is another powerful method to test the clastogenic activity of many substances for human therapy [21,22].

\section{REFERENCES}

[1] H. W. Li, H. Liu, C. E. Corrales, J. R. Risner, J. Forrester, J. R. Holt, S. Heller and A. S. B. Edge, "Differentiation of neurons from Neural Precursors Generated in Floating Spheres from Embryonic Stem Cells,” BMC Neuroscience, Vol. 10, 2009, p. 122. doi:10.1186/1471-2202-10-122

[2] M. Schuldiner, O. Yanuka, J. Itskovitz-Eldor, D. A. Melton and N. Benvenisty, "Effects of Eight Growth Factors on the Differentiation of Cells Derived from Human Embryonic Stem Cells," Proceedings of the National Academy of Sciences of USA, Vol. 97, No. 21, 2000, pp. 1130711312. doi:10.1073/pnas.97.21.11307

[3] U. S. Sohur, J. G. Emsley, B. D. Mitchell and J. D. Macklis, "Adult Neurogenesis and Cellular Brain Repair with Neural Progenitors, Precursors and Stem Cells," Philosophical Transactions of the Royal Society B: Biological Sciences, Vol. 361, No. 1473, 2006, pp. 1477-1497. doi:10.1098/rstb.2006.1887

[4] C. E. Corrales, L. Pan, H. W. Li, M. C. Liberman, S. Heller and A. S. B. Edge, "Engraftment and Differentiation of Embryonic Stem Cell-Derived Neural Progenitor Cells in the Cochlear Nerve Trunk: Growth of Processes into the Organ of Corti," Journal of Neurobiology, Vol. 66, No. 13, 2006, pp. 1489-1500. doi:10.1002/neu.20310

[5] M. Emgard, L. Holmberg, E. B. Samuelsson, B. A. Bahr, S. Falci, A. Seiger and E. Sundström, "Human Neural Precursor Cells Continue to Proliferate and Exhibit Low Cell Death after Transplantation to the Injured Rat Spinal Cord,” Brain Research, Vol. 1278, 2009, pp. 15-26. doi:10.1016/j.brainres.2009.04.012

[6] Y.-K. Chang, M.-H. Chen, Y.-H. Chiang, Y.-F. Chen, W.-H. Ma, C.-Y. Tseng, B.-W. Soong, J. H. Ho and O. K. Lee, "Mesenchymal Stem Cell Transplantation Amelioratesmotor Function Deterioration of Spinocerebellarataxia by Rescuing Cerebellar Purkinje Cells,” Journal of Biomedical Science, Vol. 18, 2011, p. 54. doi:10.1186/1423-0127-18-54

[7] E. Chu and A. Sartorelli, “Antineoplastic Chemotherapy," In: Katzung Basic \& Clinical Pharmacology, 9th Edition, The McGraw-Hill Companies, Inc., 2004, pp. 898-932.

[8] A. C. Kato, G. Touzeau, D. Bertrand and C. R. Bader, "Human Spinal Cord Neurons in Dissociated Monolayer Cultures: Morphological, Biochemical, and Electro- physiological Properties," The Journal of Neuroscience Copyright Society for Neuroscience, Vol. 5, No. 10, 1985, pp. 2750-2761.

[9] D. W. Sah, "Human Fetal Central Neurons in Culture: Voltage- and Ligand-Gated Currents," Journal of Neuro- physiology, Vol. 74, No. 5, 1995, pp. 1889-1899.

[10] L. Q. Zhao and R. D. Brinton, "Select Estrogens within the Complex Formulation of Conjugated Equine Estrogens (Premarin ${ }^{\circledR}$ ) Are Protective against Neurodegenerative Insults: Implications for a Composition of Estrogen Therapy to Promote Neuronal Function and Prevent Alzheimer's Disease,” BMC Neuroscience, Vol. 7, 2006, p. 24. doi:10.1186/1471-2202-7-24

[11] G. E. Gillies and S. McArthur, "Estrogen Actions in the Brain and the Basis for Differential Action in Men and Women: A Case for Sex-Specific Medicines," Pharmacological Reviews, Vol. 62, No. 2, 2010, pp. 155-198. doi:10.1124/pr.109.002071

[12] J. Matthews and J. A. Gustafsson, "Estrogen Signaling: A Subtle Balance between ER Alpha and ER Beta," Molecular Interventions, Vol. 3, No. 5, 2003, pp. 281-292.

[13] Z. Sheng, J. Kawano, A. Yanai, R. Fujinaga, M. Tanaka, Y. Watanabe and K. Shinoda, "Expression of Estrogen Receptors (Alpha, Beta) and Androgen Receptor in Serotonin Neurons of the Rat and Mouse Dorsal Raphe Nuclei; Sex and Species Differences," Neuroscience Research, Vol. 49, No. 2, 2004, pp. 185-196.

[14] R. J. Handa, S. Ogawa, J. M. Wang and A. E. Herbison, "Roles for Estrogen Receptor Beta in Adult Brain Function,” Journal of Neurobiology, Vol. 24, 2011, pp. 160173.

[15] B. Greco, E. A. Allegretto, M. J. Tetel and J. D. Blaustein, "Coexpression of ER_ with ER and Progestin Receptor Proteins in the Female Rat Forebrain: Effects of Estradiol Treatment," Endocrinology, Vol. 142, 2001, pp. 51725181. doi:10.1210/en.142.12.5172

[16] J. E. Donahue, E. G. Stopa, R. L. Chorsky, J. C. King, H. M. Schipper, S. A. Tobet, J. D. Blaustein and S. Reichlin, "Cells Containing Immunoreactive Estrogen ReceptorAlpha in the Human Basal Forebrain,” Brain Researvh, Vol. 856, No. 1-2, 2000, pp. 142-151. doi:10.1016/S0006-8993(99)02413-0

[17] D. Montague, C. S. Weickert, E. Tomaskovic-Crook, D. A. Rothmond, J. E. Kleinman and D. R. Rubinow, "Oestrogen Receptor Alpha Localisation in the Prefrontal Cortex of Three Mammalian Species,"Journal of Neuroendocrinology, Vol. 20, No. 7, 2008, pp. 893-903. doi:10.1111/j.1365-2826.2008.01743.x

[18] T. A. Ishunina, F. P. Kruijver, R. Balesar and D. F. Swaab, "Differential Expression of Estrogen Receptor Alpha and Beta Immunoreactivity in the Human Supraoptic Nucleus in Relation to Sex and Aging," Journal of Clinical Endocrinology and Metabolism, Vol. 85, No. 9, 2000, pp. 3283-3291. doi:10.1210/jc.85.9.3283

[19] F. F. N. Rizzzuto, "Estrogen Receptors Localization in the Spinal Trigeminal Nucleus: An Immunohistochemical Study in Humans,” European Journal of Pain, Vol. 15, No. 10, 2011, pp. 1002-1007.

[20] M. J. Gallego, P. Porayette, M. M. Kaltcheva, R. L. Bowen, S. V. Meethal and C. S. Atwood, "The Pregnancy Hormones Human Chorionic Gonadotropin and Progesterone Induce Human Embryonic Stem Cell Proliferation and Differentiation into Neuroectodermal Rosettes,” Stem 
Cell Research \& Therapy, Vol. 1, 2010, p. 28.

[21] D. Jacobson-Kram, R. J. Albertini, R. F. Branda, M. T. Falta, P. T. Iype, K. Kolodner, S.-H. Liou, M. A. McDiarmid, M. Morris, J. A. Nicklas, J. P. O’Neill, M. C. Poirier, D. Putman, P. T. Strickland, J. R. Williams and S. Xiao, "Measurement of Chromosomal Aberrations, Sister Chromatid Exchange, Hprt Mutations, and DNA Adducts in Peripheral Lymphocytes of Human Populations at In- creased Risk for Cancer," Environmental Health Perspectives, Vol. 101, No. 3, 1993, pp. 121-125.

[22] K. Siviková, J. Dianovsky and B. Holecková, “Induction of SCEs and DNA Fragmentation in Bovine Peripheral Lymphocytes by in Vitro Exposure to Tolylfluanid-Based Fungicide,” Genetics and Molecular Biology, Vol. 34, No. 1, 2011, pp. 110-115. doi:10.1590/S1415-47572010005000097 